\title{
Occurrence of anti-Toxoplasma gondii antibodies and parasite DNA in backyard chicken breeding in Northeast, Brazil
}

\author{
Ocorrência de anticorpos anti-Toxoplasma gondii e DNA do parasita em galinhas \\ de criaçóes domésticas no Nordeste, Brasil \\ Marcela Fernanda Torres Samico Fernandes ${ }^{1}$; Erika Fernanda Torres Samico Fernandes Cavalcanti ${ }^{1}$; \\ José Givanildo da Silva ${ }^{1}$; André da Rocha Motaa ${ }^{1}$ Orestes Luiz de Souza Neto ${ }^{1}$; André de Souza Santos ${ }^{1}$; \\ Pedro Paulo Feitosa de Albuquerque ${ }^{1}$; Débora Costa Viegas de Lima ${ }^{1}$; Rinaldo Aparecido Mota ${ }^{1 *}$
}

\begin{abstract}
${ }^{1}$ Laboratório de Doenças Infectocontagiosas dos Animais Domésticos, Departamento de Medicina Veterinária, Universidade Federal Rural de Pernambuco - UFRPE, Recife, PE, Brasil
\end{abstract}

Received March 9, 2015

Accepted March 16, 2015

\begin{abstract}
The aim of the present study was to investigate the occurrence of anti-Toxoplasma gondii antibodies and parasite DNA in backyard chickens bred in the metropolitan area of Recife, Brazil. In total, 212 serum samples were collected from 16 properties, and 12 backyard chickens were collected in the six sanitary districts of Recife. An indirect immunofluorescence assay (IFA) was used to investigate the occurrence of anti-Toxoplasma gondii antibodies. Polymerase chain reaction (PCR) was used to detect T. gondii DNA in brain, heart, liver and lung specimens. Of the samples analyzed by serology, 86/212 (40.56\%) were positive; of the samples analyzed by PCR, $2 / 12$ (16.7\%) were positive, with both samples positive by both tests (serological and molecular). The presence of antibody anti-T. gondii and parasite DNA in tissues of these animals are worrying aspects for public health because there is a risk of transmission of the parasite to humans through eating undercooked or raw meat. Based on the results, the adoption of preventive measures to prevent the cats access to the chickens creations should be encouraged, since these animals were identified in most of the studied properties.

Keywords: Toxoplasmosis, Gallus gallus domesticus, Indirect Immunofluorescence Assay (IFA), Polymerase Chain Reaction (PCR), Brazil.
\end{abstract}

\section{Resumo}

O objetivo do presente estudo foi investigar a ocorrência de anticorpos anti-Toxoplasma gondii e de DNA do parasito em galinhas de criaçôes domésticas, na região metropolitana de Recife, Brasil. No total, 212 amostras de soro foram coletadas de aves de 16 estabelecimentos e de 12 galinhas de criações domésticas nos seis distritos sanitários de Recife. Para a pesquisa de anticorpos anti-Toxoplasma gondii foi utilizada a Reaçáo de Imunofluorescência Indireta (RIFI). A Reaçáo em Cadeia da Polimerase (PCR) foi utilizada para detectar o DNA de T. gondii em fragmentos de cérebro, coração, fígado e pulmão. Das amostras analisadas por sorologia, 86/212 (40,56\%) foram positivas. Das amostras analisadas por PCR, 2/212 (16,7\%) foram positivas, em ambos os testes (sorológicos e moleculares). A presença de anticorpos anti-T. gondii e de DNA parasitário nos tecidos desses animais são aspectos preocupantes para saúde pública, porque há o risco de transmissão do parasita para humanos através da ingestão de carne mal cozida ou crua. Com base nos resultados obtidos, a adoção de medidas preventivas que evitem o acesso de gatos às criaçôes de galinhas deve ser incentivada, uma vez que esses animais foram identificados na maioria das propriedades estudadas.

Palavras-chave: Toxoplasmose, Gallus gallus domesticus, Reação de Imunofluorescência Indireto (RIFI), Reação em Cadeia de Polimerase (PCR), Brasil.

\footnotetext{
*Corresponding author: Rinaldo Aparecido Mota. Departamento de Medicina

Veterinária, Universidade Federal Rural de Pernambuco - UFRPE, Avenida

Dom Manoel de Medeiros, s/n, Dois Irmãos, CEP 51171-900, Recife, PE,

Brasil. e-mail: rinaldo.mota@hotmail.com
} 


\section{Introduction}

Toxoplasmosis, a zoonotic disease caused by the protozoan Toxoplasma gondii, is a cosmopolitan disease that infects humans and other warm-blooded species (MILLAR et al., 2012). Toxoplasma gondii is a protozoan with obligatory intracellular reproduction that is capable of infecting several mammals and birds (SILVEIRA, 2010), and the main transmission route of T. gondii is through the ingestion of oocysts found in the feces of definitive hosts (DUBEY et al., 1995).

Birds are important intermediary hosts of $T$. gondii. As backyard chickens are a good indicator of soil that has been contaminated with $T$. gondii oocysts, they are used as sentinel animals in regions with high rates of human infection (MILLAR et al., 2012).

A number of investigators have noted that chickens from extensive breeding programs can contain tissue cysts of $T$. gondii due to their eating habits; these birds therefore represent an infection risk for humans (LITERAK \& HEJLICEK, 1993; DUBEY et al., 2006; DUBEY, 2010). Birds bred in intensive systems are less likely to come into contact with infection sources and generally exhibit a lower prevalence of the parasite (MILLAR et al., 2008). In Brazil, $70 \%$ of people have been exposed to $T$. gondii at some point in their lives (VERGARA et al., 1985). Indeed, serological studies conducted in different regions of the country have reported prevalence rates ranging from $11.18 \%$ to $78.7 \%$ (JAMRA \& GUIMARÃES, 1981; FERRARONI \& LACAZ, 1982; ABRAHAMS-SANDI \& VARGAS-BRENES, 2005; HOLSBACK et al., 2012; ZHAO et al., 2012; IBRAHIM et al., 2014).

However, very few serological studies have been conducted in northeastern Brazil to investigate the infection of humans and backyard chickens; in fact, no such studies have been conducted in mainland Pernambuco. Nonetheless, in a study conducted on the Fernando de Noronha archipelago, $84 \%$ of the chickens assessed were positive (DUBEY, 2010). In Pernambuco, a typical dish known as "Galinha Cabidela" is prepared with poultry viscera and blood. In some cases, this dish is served "undercooked" and this regional habit can be considered a risk factor in the transmission of the parasite. The aim of the present study was to investigate the occurrence of anti-Toxoplasma gondii antibodies in backyard chickens as well as the presence of parasite DNA in the tissues of chickens bred extensively for human consumption in the city of Recife in northeastern Brazil.

\section{Materials and Methods}

The experimental procedures of the present study followed the International Guiding Principles for Biomedical Research Involving Animals and were approved by the Ethics Committee of the Universidade Federal Rural de Pernambuco under protocol number CEUA-UFRPE - 015533/2012-71.

Blood samples were collected from backyard chickens in the metropolitan area of Recife, Northeast Brazil. The sample size was determined using an expected prevalence of $10 \%$ T. gondii infection (GARCIA et al., 2000), a confidence interval of $95 \%$ and a statistical error of $5 \%$ (THRUSFIELD, 2004). These calculations led to the establishment of a minimal sample of 138 birds. As a safety margin, 212 samples were collected. The properties were sampled in a non-probabilistic convenient manner.

Blood was collected through brachial venipuncture. An indirect immunofluorescence assay (IFA) was used to detect IgG antibodies against T. gondii (CAMARGO, 1974). Serial dilutions from 2 to 1024 were used. Sera that had titers equal to or greater than 16 were considered positive (MILLAR et al., 2012). Tachyzoites of the RH strain were used to sensitize the slides. Negative and positive controls were included in the reactions.

To study the parasite DNA, 12 chickens were acquired, in a non-probabilistic convenient manner, from the most popular public markets in the six sanitary districts of Recife. Blood collection for IFA and tissue fragment collection from the brain, heart, lung and liver was carried out after euthanasia by cervical dislocation according to resolution number 714 of the Conselho Federal de Medicina Veterinária (20th of June 2002). The samples first underwent DNA extraction using the QIAamp Tissue kit (Qiagen), following the manufacturer's instructions. DNA was amplified in a final reaction volume of $12.5 \mu \mathrm{L}$ containing the following: $2.5 \mu \mathrm{L}$ of genomic DNA, $0.5 \mu \mathrm{M}$ of each primer, $2.75 \mu \mathrm{L}$ of ultrapure Milli-Q water and $6.25 \mu \mathrm{L}$ of MasterMix (PCR mixture - Qiagen). The PCR was conducted in a MJ-96G thermocycler (Biocycle Co. Ltd, Hangzhou - China), as described by (HOMAN et al., 2000). The primer pairs used in the PCR were TOX4 (CGCTGCAGGGAGGAAGACGAAAGTTG) and TOX5 (CGCTGCAGACACAGTGCATCTGGATT), which amplify a 529 bp region and were previously described by Homan et al. (2000). The amplified products were detected by electrophoresis in $2 \%$ agarose gels, stained with ethidium bromide, visualized under ultra-violet light and photographed. Measures were taken to avoid contaminating the samples from the time of collection until the results were available, as described in (KWOK, 1990).

The positive control for the extraction of parasite DNA was a suspension of $\mathrm{RH}$ strain tachyzoites at a concentration of $10^{4}$ tachyzoites $/ \mathrm{mL}$. The negative control was ultrapure water. DNA sequencing was used to confirm the identity of the amplified fragments.

The amplicons were purified using the Qiacki purification Kit following the manufacturer's instructions and forwarded to the Central Laboratory (LABCEN) of the Center of Biological Sciences (CCB) of the Universidade Federal de Pernambuco (UFPE). Subsequently, the sequences were analyzed with the aid of Bioedit and MEGA 5 software and compared with the NCBI database using BLAST.

\section{Results}

Based on the serological analysis, $40.56 \%$ (86/212) of the samples were positive for anti- $T$. gondii antibodies. The positive chickens had titers ranging from 16 to 256 , and the IgG antibody titers are shown in Table 1.

Positive PCR amplification of $T$. gondii DNA was recorded in $16.6 \%(2 / 12)$ of the heart and lung samples. The molecular identification of the amplicons found in the present study indicated a $99 \%$ similarity with $T$. gondii DNA recorded in GenBank (accession number JQ235841.1). 
Table 1. Distribution of IgG anti-T. gondii titers by indirect immunofluorescence assay in positive chickens.

\begin{tabular}{ccc}
\hline Titer & AF(N) & RF (\%) \\
\hline $1: 16$ & 36 & 42 \\
$1: 32$ & 21 & 25 \\
$1: 64$ & 13 & 15 \\
$1: 128$ & 8 & 9 \\
$1: 256$ & 8 & 9 \\
Total & 86 & 100 \\
\hline
\end{tabular}

AF: Absolute frequency; RF: Relative frequency; N: Number.

\section{Discussion}

A high frequency of positive chickens was determined by serology in the present study (40.56\%). This result is significant when compared to results from other regions of Brazil. In addition, the results for South America vary in relation to indices of positivity: $44 \%$ in Colombia (DUBEY et al., 2005a), 26\% in Peru (DUBEY et al., 2004), 32\% in Venezuela (DUBEY et al., 2005b), and 40\% in Argentina (DUBEY et al., 2005c). All of these studies used the modified agglutination test (MAT) and considered sera with titers $\geq 5$ as positive.

Previous studies have been conducted in Brazil to assess the prevalence of $T$. gondii in backyard chickens, with results ranging from 10.3\% (GARCIA et al., 2000) to 81\% (DUBEY et al., 2003). However, studies of this species in the state of Pernambuco remain scarce; only the studies conducted by Dubey et al. (2008) and Dubey (2010) have characterized T. gondii strains in chickens in this state. The differences in infection rates between countries and regions of the same country may be explained by different levels of environmental contamination, the techniques used, the climate and the breeding systems employed, among other factors (MILLAR et al., 2012).

The high frequency of infected chickens found in the present study was because the birds were bred in an extensive system that involved contact with soil or water that had been contaminated with oocysts. Young and adult cats shared the same space as the chickens on all of the 16 properties visited in the present study, and infected cats can contaminate an area with oocysts (DUBEY et al., 1995). The chickens used in the present study were adults, with an increased possibility of contact with infection sources over time.

In the present study, the amplification of $T$. gondii DNA was also observed in heart and lung samples from different backyard chickens. Of the 12 chickens studied, two (16.66\%) were positive by PCR. The presence of parasite DNA in these organs is a significant finding. Although it is not possible to confirm the viability of the parasite using PCR testing, the results call into question whether the consumption of this type of meat could be a risk to the consumer, particularly if the meat or viscera are undercooked (MILLAR et al., 2012).

Yan et al. (2010) studied chickens in China and reported that the organs with the greatest quantity of $T$. gondii parasites were the heart and lungs, and Aigner et al. (2010) demonstrated the amplification of T. gondii DNA in chicken brain and heart samples in Paraná (Brazil). The present study also confirmed positivity in lung and heart samples. In general, this type of investigation uses the brain and heart for molecular analysis because these organs are the targets of the parasite. Gonçalves (2010) obtained 13 brain samples and seven heart samples in Bahia (Brazil) and reported that 8 samples (from both organs) were positive by PCR, thereby demonstrating a greater predilection of the pathogen for these organs.

\section{Conclusion}

The high frequency of positive animals in the present study should be a concern for health authorities because there is a risk of the parasite being transmitted to humans, particularly in the northeastern region, where the meat and viscera of backyard chickens are commonly consumed.

In relation to the occurrence of anti- $T$. gondii antibodies and DNA amplification of the parasite in the tissues from backyard chickens, the results of the present study are specific to this region of Brazil. Based on the results, the adoption of preventive measures to prevent the cats access to the chickens creations should be encouraged, since these animals were identified in most of the studied properties.

\section{References}

Abrahams-Sandi E, Vargas-Brenes O. Serological prevalence of Toxoplasma gondii in free-range chickens from Costa Rica. Trop Anim Health Prod 2005; 37(5): 369-372. http://dx.doi.org/10.1007/s11250-005-5689-6. PMid:16274008.

Aigner CP, Silva AV, Sandrini F, Osório PS, Poiares L, Largura A. Realtime PCR-based quantification of Toxoplasma gondii in tissue samples of serologically positive outdoor chickens. Mem Inst Oswaldo Cruz 2010; 105(7): 935-937. http://dx.doi.org/10.1590/S0074-02762010000700018. PMid:21120368.

Camargo ME. Introdução às técnicas de imunofluorescência. Rev Bras Patol Clín 1974; 10(3): 87-107.

Dubey JP, Gennari SM, Labruna MB, Camargo LM, Vianna MC, Marcet PL, et al. Characterization of Toxoplasma gondii isolates in free-range chinkens from Amazon, Brasil. J Parasitol 2006; 92(1): 36-40. http:// dx.doi.org/10.1645/GE-655R.1. PMid:16629312.

Dubey JP, Gomez-Marin JE, Bedoya A, Lora A, Vianna MC, Hill D, et al. Genetic and Biologic characteristics of Toxoplasma gondii isolates in free-range chickens from Colômbia, South América. Vet Parasitol 2005a; 134(1-2): 67-72. http://dx.doi.org/10.1016/j.vetpar.2005.07.013. PMid:16105721.

Dubey JP, Lenhart A, Castillo CE, Alvarez L, Marcet P, Sreekumar C, et al. Toxoplasma gondii infections in chickens from Venezuela: isolation, tissue distribution, and molecular characterization. J Parasitol 2005b; 91(6): 1332-1334. http://dx.doi.org/10.1645/GE-500R.1. PMid:16539013.

Dubey JP, Marcet P, Lehmann T. Characterization of Toxoplasma gondii isolates in free-range chickens from Argentina. J Parasitol 2005c; 91(6): 1335-1339. http://dx.doi.org/10.1645/GE-575R.1. PMid:16539014.

Dubey JP, Levy MZ, Sreekumar C, Kwok OC, Shen SK, Dahl E, et al. Tissue distribution and molecular characterization of chickens isolates of 
Toxoplasma gondii from Peru. J Parasitol 2004; 90(5): 1015-1018. http:// dx.doi.org/10.1645/GE-329R. PMid:15562600.

Dubey JP, Navarro IT, Graham DH, Dahl E, Freire RL, Prudencio LB, et al. Characterization of Toxoplasma gondii isolates from free range chickens from Paraná, Brazil. Vet Parasitol 2003; 117(3): 229-234. http:// dx.doi.org/10.1016/j.vetpar.2003.09.003. PMid:14630431.

Dubey JP, Velmurugan GV, Chockalingam A, Pena HFJ, Oliveira LN, Leifer CA, et al. Genetic diversity of Toxoplasma gondii isolates from chickens from Brazil. Vet Parasitol 2008; 157(3-4): 299-305. http:// dx.doi.org/10.1016/j.vetpar.2008.07.036. PMid:18804329.

Dubey JP, Weigel MR, Siegel AM, Thulliez P, Kitron UD, Mitchell MA, et al. Sources and reservoirs of Toxoplasma gondii infection on 47 swine farms in Illinois. J Parasitol 1995; 81(5): 723-729. http://dx.doi. org/10.2307/3283961. PMid:7472862.

Dubey JP. Toxoplasma gondii infections in chickens (Gallus domesticus): prevalence, clinical disease, diagnosis, and public health significance. Zoonoses Public Health 2010; 57(1): 60-73. http://dx.doi.org/10.1111/ j.1863-2378.2009.01274.x. PMid:19744305.

Ferraroni JJ, Lacaz CS. Prevalência de anticorpos contra agentes causadores da hepatite, malária, sífilis e toxoplasmose em cinco populaçóes humanas distintas da Amazônia Brasileira. Rev Inst Med Trop Sao Paulo 1982; 24(3): 155-161. PMid:6760350.

Garcia JL, Navarro IT, Ogawa L, Marana ERM. Soroprevalência do Toxoplasma gondii em galinhas (Gallus gallus domesticus) de criaçóes domésticas, oriundas de propriedades rurais do Norte do Paraná, Brasil. Cienc Rural 2000; 30(1): 123-127. http://dx.doi.org/10.1590/S010384782000000100020

Gonçalves IN. Investigação sorológica, molecular e isolamento de Coccídios toxoplasmatineos em galinhas (Gallus domesticus). [Dissertation]. Salvador: Universidade Federal da Bahia; 2010.

Holsback I, Pena HFJ, Ragozo A, Lopes EG, Gennari SM, Soares RM. Serologic and molecular diagnostic and bioassay in mice for detection of Toxoplasma gondii in free ranges chickens from Pantanal of Mato Grosso do Sul. Pesqui Vet Bras 2012; 32(8): 721-726. http://dx.doi.org/10.1590/ S0100-736X2012000800007.

Homan WL, Vercammen M, De Braekeleer J, Verschueren H. Identification of a 200- to 300 fold repetitive 529 bp DNA fragment in Toxoplasma gondii, and its use for diagnostic and quantitative PCR. Int J Parasitol 2000; 30(1): 69-75. http://dx.doi.org/10.1016/S0020-7519(99)001708. PMid:10675747.
Ibrahim HM, Abdel-Ghaffar F, Osman GY, El-Shourbagy SH, Nishikawa HY, Khattab RA. Prevalence of Toxoplasma gondii in Chicken samples from delta of Egypt using ELISA, histopathology and immunohistochemistry. J Parasit Dis 2014; 38: 1-6. PMid:24505168.

Jamra LMF, Guimarães EC. Conversão sorológica para Toxoplasmose em crianças de um centro de saúde de São Paulo. Rev Inst Med Trop Sao Paulo 1981; 23(3): 133-137. PMid:7280479.

Kwok S. Procedures to minimize PCR-product carry-over. In: Innis MA, Gelfan DH, Sninsky JJ, White TJ. PCR protocols: a guide to methods and applications. San Diego: Academic Press; 1990. p. 482.

Literak I, Hejlicek K. Incidence of Toxoplasma gondii in population of domestic birds in the Czech Replubic. Avian Pathol 1993; 22(2): $275-$ 281. http://dx.doi.org/10.1080/03079459308418920. PMid:18671017.

Millar PR, Alves FMX, Teixeira VQ, Vicente RT, Menezes EM, Sobreiro LG, et al. Occurrence of infection with Toxoplasma gondii and factors associated with transmission in broiler chickens and laying hens in different raising systems. Pesqui Vet Bras 2012; 32(3): 231-236. http:// dx.doi.org/10.1590/S0100-736X2012000300009.

Millar PR, Sobreiro LG, Bonna ICF, Amendoeira MR. A importância dos animais de produção na infecção por Toxoplasma gondii no Brasil. Semina: Ciênc Agrár 2008; 29(3): 693-706.

Silveira LH. Caracterização biológica e genotípica de isolados de Toxoplasma gondii obtidos de galinhas de criação livre do Pantanal do Mato Grosso do Sul [Thesis]. São Paulo: Universidade de São Paulo; 2010.

Thrusfield M. Veterinary epidemiology. 2th ed. Cambridge: Blackwell Science; 2004

Vergara TRC, Gonçalves AJR, Oliveira CAB, Carvalho JJ, Finkel N, Almeida RMM, et al. Epidemia de toxoplasmose do sistema nervoso central em enfermos com AIDS na cidade do Rio de Janeiro. Arq Bras Med Vet Zootec 1985; 59: 397-406.

Yan C, Yue CL, Yuan ZG, Lin RQ, He Y, Yin CC, et al. Molecular and serological diagnosis of Toxoplasma gondii infection in experimentally infected chickens. Vet Parasitol 2010; 173(3-4): 179-183. http://dx.doi. org/10.1016/j.vetpar.2010.07.011. PMid:20728997.

Zhao G, Shen B, Xie Q, Xu LX, Yan RF, Song XK, et al. Detection of Toxoplasma gondii in free-range chickens in China based on circulating antigens and antibodies. Vet Parasitol 2012; 185(2-4): 72-77. http:// dx.doi.org/10.1016/j.vetpar.2011.10.031. PMid:22153258. 